\title{
Pemanfaatan Rubrik Sebagai Instrumen Penilaian Alternatif
}

\author{
Wiyun Philipus Tangkin \\ wiyun.tangkin@uph.edu \\ Universitas Pelita Harapan
}

The Use Of Rubric As Alternative Assessment Instrument

\begin{abstract}
This research aims at describing clearly about the contribution of using rubric as alternative assessment towards students learning motivation. This research was conducted at Dian Harapan Karawaci in grade IX junior high school. This is a descriptive qualitative research, the data collection uses interview, questionnaire, and documents. The interview involved five science teachers (who teach physics, biology, and chemistry) and 15 students of grade IX. The data in the form of questionnaire were gathered from teachers and students, analyzed by using statistic in order to obtain the percentage of answer from the teachers and students. It is concluded that the rubric of assessment has close relationship with students learning motivation. In its contribution, rubric as a means of assessment is able to motivate students learning.
\end{abstract}

Keywords: Rubric, Assessment, Student Motivation

Received date: 2 Juli 2018

Article Info

Revised date: 24 Desember 2018 Accepted date: 22 Januari 2019

\section{PENDAHULUAN}

Pergantian kurikulum pendidikan yang intensitasnya cukup tinggi membuat pola pembelajaran tidak menentu, sehingga buku teks, model pembelajaran, dan cara penilaian juga ikut berubah. Setiap manusia mempunyai panca indera dan mempunyai gaya belajar yang berbeda-beda. Panca indera tersebut membantu setiap manusia dalam proses pembelajaran. Oleh karena itu sangat tidak efektif jika suatu pembelajaran hanya menggunakan penilaian yang baku saja, padahal siswa juga perlu belajar untuk tampil dan melontarkan pendapatnya atau dengan mengeskspresikan dirinya dalam bentuk apapun. Dengan demikian suatu penilaian perlu memperhatikan aspek-aspek yang juga perlu dinilai dan dikembangkan dalam suatu pembelajaran siswa selain hanya aspek kognitif siswa saja.

Jenis penilaian yang sering digunakan adalah tes tulis. Tes tulis merupakan tes tradisional dimana konteks pengertiannya adalah tes yang menggunakan perangkat tes obyektif juga merupakan tes yang dirancang lengkap dengan jawabannya, dan umumnya diselenggarakan berupa tes kertas dan pensil. Secara umum tes ini dapat dibagi menjadi dua macam yaitu tes uraian (essay test) dan tes obyektif. Tes tulis dianggap relatif lebih mudah, hemat dalam penyusunannya dan membutuhkan waktu yang cukup singkat dalam penyelenggaraannya. Kondisi inilah yang menyebabkan kita seringkali menyimpulkan bahwa seakan-seakan pelaksanaan tes tulis lah yang paling cocok bagi sistem penilaian di Indonesia. Walau demikian, bukan berarti bahwa tes tulis tidak layak diberikan, namun peneliti berpendapat bahwa pengukuran dan penilaian terhadap tingkat keberhasilan belajar seorang peserta didik tidak cukup hanya berdasarkan pelaksanaan tes tulis semata yang hasilnya berwujud suatu angka tertentu.

\section{KAJIAN PUSTAKA}

Menurut Peraturan Menteri dan Kebudayaan Republik Indonesia No. 64 Tahun 2013 Standar kompetensi lulusan mencakup sikap (afektif), pengetahuan (kognitif), dan keterampilan (psikomotorik). Howard Gardner 1983 (dalam Raharjo 2010, 312), mengatakan bahwa kita cenderung lebih menghargai orang-orang yang ahli dalam kemampuan logika (matematika) dan bahasa. Kita harus memberikan perhatian yang seimbang terhadap orang-orang yang memiliki talenta (gift) di 
dalam kecerdasan lainnya seperti artis, arsitek, musikus, ahli alam, designer, penari, terapis, entrepreuners, dan lain-lain. Teori ini memperlihatkan secara jelas, bahwa penilaian hasil maupun proses belajar tidak hanya mengukur salah satu atau beberapa kemampuan siswa, tetapi harus mengukur seluruh aspek kemampuan siswa.

Peraturan Menteri Pendidikan dan Kebudayaan Nomor 104 Tahun 2014 tentang Penilaian Hasil Belajar oleh Pendidik pada Pendidikan Dasar dan Pendidikan Menengah menyatakan bahwa pelaksanaan Kurikulum 2013 mempersyaratkan penggunaan penilaian otentik (authentic assessment). Penilaian otentik menekankan pada pentingnya penerapan keterampilan dan kemampuan dalam menyelesaikan tugas pada situasi dunia nyata (Arends, 2012:245).

Penilaian alternatif yang cocok digunakan saat ini adalah rubrik karena dalam kontribusinya, rubrik digunakan untuk menilai kinerja siswa mencakup aspek afektif dan psikomotorik siswa yang merupakan cakupan aspek pembelajaran, yang dianggap sama pentingnya dengan aspek kognitif. Rubrik juga dapat digunakan dalam bidang yang lain bahkan dalam tingkat pendidikan yang rendah sampai yang tinggi. Rubrik dalam penggunaannya, tidak hanya untuk menilai performance (kinerja), akan tetapi juga dapat digunakan untuk menilai project siswa.

Peneltian ini bertujuan mamaparkan dengan jelas kontribusi rubrik sebagai instrumen penilaian alternatif dalam proses belajar siswa, terutama bagi motivasi belajar mereka.

\section{METODE PENELITIAN}

Penelitian ini menggunakan metode penelitian kualitatif deskriptif. Instrumen penelitian yang digunakan meliputi wawancara, angket, dan data nilai siswa yang diperoleh dengan menggunakan rubrik penilaian. Tempat penelitian adalah salah satu sekolah di Karawaci-Tangerang. Subyek penelitian ini adalah lima guru IPA (dua guru fisika, dua guru biologi, dan satu guru kimia) dan siswa kelas IX

Wawancara dilakukan antara peneliti dengan partisipan yaitu lima guru bidang studi IPA dan 15 siswa kelas IX SMP Dian Harapan Karawaci. Data berupa angket diperoleh dari lima guru bidang studi IPA dan 123 siswa kelas IX. Angket guru terbagi dalam dua macam penyataan dan masingmasing berjumlah 15 pernyataan. Jenis pernyataan yang pertama, tentang rubrik sebagai penilaian dan yang kedua, tentang kontribusi rubrik penilaian terhadap motivasi belajar siswa.

\section{HASIL PENELITIAN DAN PEMBAHASAN}

\section{Pemahaman dan Tanggapan Guru terhadap Penggunaan Rubrik}

Dari hasil wawancara dengan para guru mengenai penggunaan rubrik sebagai instrumen penilaian alternatif, peneliti menemukan bahwa kelima guru berpendapat bahwa rubrik merupakan instrumen penilaian alternatif yang sangat baik, dengan demikian rubrik merupakan instrumen penilaian yang penting untuk digunakan. Rubrik dikatakan sebagai instrumen penilaian alternatif yang sangat baik karena melalui rubrik, siswa mampu untuk memotivasi diri sendiri dalam hal mencapai kriteria-kriteria yang sudah disepakati, dalam hal bersosialisasi dengan teman-temannya (misalnya dengan membagi tugas kelompok, dan mengajari temannya), siswa juga belajar kreatif dan disiplin, dengan mengumpulkan tugas tepat waktu.

Menurut para guru, rubrik juga merupakan penilaian yang obyektif, karena dalam rubrik penilaian, terdapat kriteria-kriteria dan skor yang merupakan panduan dalam menilai. Jadi orang yang berperan sebagai penilai tidak dapat memberikan penilaian di luar dari kriteria-kriteria yang sudah ditentukan. Dengan demikian siswa pun dapat terlibat untuk menilai teman-temannya pada saat performance. Seperti pengalaman beberapa guru yang menyatakan bahwa mereka pernah melibatkan siswa untuk menilai temannya yang sedang presentasi, dan dampaknya adalah siswa menjadi percaya diri dan bertanggung jawab, karena penilaian tidak hanya bersifat sepihak dari guru saja melainkan dari siswa juga.

Kesimpulan peneliti mengenai pemahaman guru dalam penggunaan rubrik sebagai instrumen penilaian alternatif ialah sangat penting karena dalam kontribusinya rubrik penilaian dapat mencakup aspek kognitif, psikomotorik dan afektif siswa. 


\section{Peran Guru dalam Penggunaan Rubrik sebagai Instrumen Penilaian}

Berdasarkan pernyataan dari kelima guru, peneliti menemukan bahwa selama penggunaan rubrik, guru berperan sebagai penilai, observer, fasilitator, pembelajar, pengontrol, dan motivator. Dari hasil wawancara, para guru berpendapat bahwa peranan guru sangat penting dalam menggunakan penilaian rubrik. Bahkan dari awal penggunaan rubrik penilaian, guru harus mengkomunikasikan dengan siswa, dalam hal ini guru berperan sebagai fasilitator. Siswa akan terdorong untuk belajar dan mempersiapkan langkah-langkah dalam mengerjakan tugas jika siswa mengerti kriteria-kriteria dalam penilaian. Sebaliknya siswa tidak akan menunjukkan kemajuan didalam belajar jika siswa tidak mengerti kriteria-kriteria dalam penilaian. Pada saat siswa melakukan kegiatan yang akan dinilai, guru juga berperan sebagai observer dan penilai. Selain memberikan penilaian terhadap siswa, guru juga berkewajiban untuk mengontrol jalannya kegiatan yang dinilai. Menurut pernyataan guru A, sering siswa bingung ketika presentasi di kelas maka yang biasanya dilakukan guru adalah menjadi moderator agar membantu siswa mempersiapkan diri untuk presentasi.

Dari hasil wawancara, guru A, guru C, dan guru D juga mengatakan bahwa melalui rubrik penilaian, guru juga menjadi pembelajar. Guru mengevaluasi pengajarannya selama penilaian berlangsung dan setelah melakukan penilaian. Guru mampu mengevaluasi secara detail dengan melihat kriteria-kriteria dalam rubrik penilaian. Misalnya dengan melihat pencapaian siswa dalam kriteria isi dan materi, guru dapat menghubungkan dengan pengajarannya, apakah tercapai atau tidak.

\section{Pendapat Guru mengenai Respon Siswa Terhadap Rubrik Penilaian}

Pendapat guru A, C, D, dan E mengenai bagaimana respon siswa terhadap rubrik sebagai penilaian ialah sebagian besar siswa antusias dengan diberlakukannya rubrik. Memang ada beberapa siswa yang kurang antusias namun akhirnya mereka juga turut aktif dalam mempersiapkan tugasnya karena biasa dikerjakan dalam kelompok.

Dari pernyataan guru, dapat disimpulkan bahwa siswa antusias, karena siswa mengerti tujuan dari kriteria-kriteria dalam rubrik melalui penjelasan guru, sebelum siswa mengerjakan tugas. Penjelasan guru tentang kriteria-kriteria, juga didiskusikan dengan siswa, dengan demikian siswa merasa terlibat dalam menentukan kriteria yang akan diberlakukan dalam menilai kinerja mereka.

Lain halnya dengan pendapat guru D yang mengatakan bahwa respon siswa tergantung dari tingkat kelasnya. Guru D menganalisa melalui pengalamannya bahwa respon siswa kelas VII, berbeda dengan kelas VIII dan kelas IX. Guru D menyimpulkan hal ini disebabkan karena usia siswa kelas VII masih terbawa sifat kanak-kanak yang masih lebih tertarik dengan reward. Sedangkan respon kelas VIII dan kelas IX sudah lebih mengerti maksud dan tujuan dari kriteria penilaian yang disampaikan oleh guru sehingga siswa kelas VIII dan IX sudah mampu memikirkan bagaimana mengerjakan tugas yang sesuai diharapkan oleh kriteria-kriteria penilaian.

Pengetahuan siswa tentang kriteria-kriteria dalam rubrik merupakan kisi-kisi bagi siswa. Dengan demikian siswa menjadi mengerti apa yang harus dilakukan dan bagaimana mencapai kriteria-kriteria dalam rubrik penilaian. Kriteria-kriteria yang terkandung dalam rubrik penilaian merupakan gambaran besar dari tugas yang akan dikerjakan siswa. Pengetahuan siswa dipengaruhi oleh penjelasan guru.

\section{Hasil Wawancara dengan Siswa}

Berikut ini, peneliti akan menjabarkan hasil wawancara dengan 15 siswa yang terlibat dalam penelitian ini. Seperti yang sudah peneliti kemukakan dalam Bab 3.2. mengenai subyek penelitian, bahwa 15 siswa kelas IX ini, dipilih untuk mewakili keseluruhan siswa kelas IX yang berjumlah 123 orang. Kelima belas siswa ini merupakan siswa kelas IX.

\section{Pemahaman Siswa mengenai Keberadaan Rubrik Penilaian}

Berdasarkan jawaban para siswa, peneliti menemukan bahwa kelima belas siswa ini mengerti dengan jelas mengenai rubrik penilaian. Ketika ditanya tentang pemahamannya tentang rubrik, maka setiap siswa spontan menjawab "tahu", dan ketika diminta untuk menjelaskan pemahamannya, semuanya menjawab dengan menyebutkan kriteria-kriteria seperti kerjasama, kreativitas, isi, dan ketepatan waktu. Peneliti menyimpulkan bahwa siswa lebih mengenal rubrik penilaian berupa kriteria-kriteria yang diberlakukan kepada mereka. Hal ini wajar karena biasanya guru hanya mengkomunikasikan mengenai kriteria-kriteria dan skornya saja. Siswa juga hanya tertarik dengan kriteria-kriteria dan berapa skor yang terkandung dalam setiap kriteria tersebut. Dengan pengetahuan yang jelas mengenai kriteria rubrik, siswa mengetahui apa yang harus dilakukan untuk memenuhi kriteria yang diharapkan. 


\section{Pemahaman serta Respon Siswa mengenai Tujuan Penggunaan Rubrik}

Dari hasil wawancara siswa mengenai tujuan penggunaan rubrik maka peneliti menemukan bahwa kelima belas siswa tersebut menjawab bahwa tujuan dari rubrik adalah untuk menilai performance mereka, dalam hal ini mencakup tugas project, presentasi, dan laporan praktikum. Para siswa berpendapat bahwa rubrik penilaian sering digunakan untuk menilai performance mereka, khususnya dalam mata pelajaran IPA (fisika, biologi dan kimia).

Ketika ditanya mengenai respon mereka dengan penggunaan rubrik sebagai instrumen penilaian, kelima belas siswa tersebut menjawab sangat senang dengan diberlakukannya rubrik penilaian, ketika ditanya alasannya mereka senang karena kriteria-kriteria yang akan diberlakukan kepada mereka selalu diberitahukan oleh guru di awal pemberian tugas. Menurut para siswa, dengan mengetahui kriteria-kriteria dalam rubrik penilaian maka mereka menjadi fokus dalam mengerjakan tugas, dan menjadi tahu apa yang harus dikerjakan.

Ada juga siswa yang berpendapat bahwa dia senang dengan rubrik karena mempunyai banyak kriteria. Dengan banyaknya kriteria maka ketika siswa mendapat skor yang rendah dari kriteria yang satu, maka siswa akan berusaha mendapat skor yang tinggi pada kriteria-kriteria yang lainnya. Misalnya jika siswa terlambat mengumpulkan tugas project maka konsekuensinya ialah mendapat skor yang kurang dari maksimal, Oleh karena itu siswa akan berusaha maksimal untuk mencapai skor yang tinggi dari kriteria-kriteria yang lainnya seperti kreativitas, kerja sama atau yang lainnya, agar menutupi skor yang kurang.

\section{Tanggapan Siswa mengenai Penjelasan Guru tentang Rubrik Penilaian}

Dari hasil wawancara mengenai penjelasan guru tentang rubrik, kelima belas siswa yang diwawancarai mengatakan bahwa guru selalu memberitahukan dan menjelaskan mengenai kriteriakriteria rubrik di awal pemberian tugas. Tidak pernah guru memberitahukan kriteria-kriteria rubrik setelah penilaian tugas dilakukan. Menurut para siswa, pada saat menjelaskan kriteria-kriteria penilaian, ada juga beberapa guru yang membagikan lembaran rubrik penilaian kepada siswa, dengan tujuan agar siswa lebih mengerti mengenai kriteria-kriteria yang akan diberlakukan.

Beberapa siswa yang diwawancarai mengatakan bahwa penjelasan guru mengenai kriteriakriteria penilaian rubrik, kadang kurang jelas, sehingga siswa tidak mengetahui bagaimana memenuhi kriteria-kriteria dalam rubrik penilaian. Menurut peneliti guru kurang menjelaskan rubrik disebabkan oleh keterbatasan waktu dalam menjelaskan. Kejelasan informasi akan sangat mempengaruhi usaha siswa dalam mengerjakan tugas yang diberikan karena dengan pengertian yang jelas maka siswa mengetahui bagaimana mencapai target dalam penilaian tersebut. Oleh karena itu guru perlu menjelaskan dengan memberikan contoh-contoh kepada siswa tentang bagaimana memenuhi kriteriakriteria dalam rubrik.

\section{Kontribusi Rubrik sebagai Instrumen Penilaian terhadap Motivasi Belajar Siswa}

Mengacu pada apa yang disampaikan oleh lima orang guru mengenai kontribusi rubrik sebagai instrumen penilaian terhadap motivasi belajar siswa, maka peneliti menemukan bahwa rubrik mempunyai hubungan dan pengaruh terhadap motivasi belajar siswa. Kelima orang guru berpendapat bahwa rubrik penilaian dapat memotivasi siswa dalam belajar.Motivasi belajar siswa terlihat dari usaha siswa untuk memenuhi kriteria-kriteria dalam rubrik. Siswa akan berusaha memenuhi kriteriakriteria dalam rubrik jika siswa mengetahui kriteria-kriteria yang akan diberlakukan kepada mereka.

Menurut Shirran (2008, 5), kriteria-kriteria yang disusun dan kemudian akan diberlakukan kepada siswa adalah untuk mengukur pengetahuan siswa, oleh karena itu, kriteria-kriteria tersebut harus disosialisasikan kepada siswa agar siswa tidak merasa bingung dan merasa dijebak karena tidak mengetahui kriteria-kriteria tersebut. Sama halnya dengan bermain bola, pemain harus mengetahui aturan mainnya, apa yang harus dilakukan dan apa yang tidak boleh dilakukan untuk menang. Demikian pula siswa harus mengetahui aturan main dalam penilaian jika siswa tersebut ingin berhasil.

Menurut Uno (2010,23), salah satu indikator motivasi belajar siswa ialah adanya hasrat untuk berhasil. Sama halnya jika kriteria-kriteria dalam penilaian dikomunikasikan maka akan timbul hasrat dalam diri siswa untuk berhasil. Hal ini juga dikatakan oleh Imanuel W., $(2017,2)$ motivasi adalah suatu usaha yang disadari untuk menggerakkan, mengarahkan, dan menjaga tingkah laku seseorang agar ia terdorong untuk melakukan sesuatu sehingga mencapai hasil atau tujuan tertentu. Selain indikator motivasi belajar, ciri-ciri siswa yang termotivasi dalam belajar juga dikemukakan oleh Emda (2017, 181-182) bahwa siswa yang termotivasi dalam belajar, akan tekun menghadapi tugas, ulet menghadapi kesulitan, menunjukkan minat, senang mencari dan memecahkan soal. Ciri-ciri tersebut 
diungkapkan oleh para guru bahwa siswa terlihat termotivasi, misalnya dalam penilaian tugas project terdapat kriteria tentang waktu pengumpulannya. Skor yang akan diperoleh oleh siswa jika mengumpulkan tepat waktu akan berbeda dengan siswa yang mengumpulkan terlambat dari waktu yang ditentukan. Berangkat dari kriteria tersebut, maka siswa berusaha mencapai skor yang tertinggi yaitu dengan mengumpulkan tugas project tepat waktu. Motivasi belajar siswa juga terlihat dari usaha siswa untuk memenuhi kriteria isi materi dalam rubrik, misalnya dalam presentasi siswa berusaha mencari sumber lain berupa buku-buku, koran, majalah, atau internet agar dapat memberikan informasi yang lebih dari pada yang sudah tercantum di buku teks mereka.

Salah seorang guru menceritakan pengalamannya, bahwa sebelum menggunakan rubrik, siswa cenderung terlambat bahkan ada yang tidak mengumpulkan tugas, sangat berbeda setelah menggunakan rubrik. Kecenderungan siswa untuk terlambat mengumpulkan tugas sangat sedikit, yang terjadi malah sebaliknya, guru tidak perlu menagih-nagih tugas siswa, karena dengan sendirinya siswa akan mengumpulkan tugas tepat pada waktunya bahkan ada yang mengumpulkan sebelum waktu pengumpulan. Hal ini menunjukkan bahwa ada usaha dari siswa untuk memenuhi kriteriakriteria dalam rubrik, walaupun menurut pengamatan, siswa termotivasi awalnya karena orientasi pada skor tertinggi dari kriteria-kriteria yang ada, akan tetapi tanpa siswa sadari, siswa melakukan pembelajaran melalui usaha-usaha yang dilakukannya untuk memenuhi kriteria-kriteria dalam rubrik tersebut.

Berdasarkan hasil wawancara dengan kelima guru, peneliti menyimpulkan bahwa ada hubungan sebab akibat yang erat antara kontribusi rubrik dengan motivasi belajar siswa. Dimana kriteria dan skor yang terdapat dalam rubrik penilaian, memotivasi siswa dalam hal pembelajaran. Hal ini berdampak positif baik terhadap guru maupun siswa. Dampak positifnya adalah guru merasa terbantu dalam pengajarannya dan siswa termotivasi untuk belajar. Guru dapat memanfaatkan kriteriakriteria dalam rubrik penilaian tersebut untuk memotivasi siswa belajar, oleh karena itu guru harus jeli dalam menentukan kriteria-kriteria yang akan diberlakukan, agar tujuan dari pembelajaran siswa tercapai.

Analisis Data Angket Guru terhadap Kontribusi Rubrik sebagai Instrumen Penilaian terhadap Motivasi Belajar Siswa

Dari hasil angket guru tentang kontribusi rubrik sebagai instrumen penilaian terhadap motivasi belajar siswa, didapat hasil sebagai berikut:

\begin{tabular}{llll}
\hline \multicolumn{3}{c}{ Keterangan } \\
\hline SS & Sangat Setuju & TS & Tidak Setuju \\
\hline S & Setuju & STS & Sangat Tidak Setuju \\
\hline
\end{tabular}

\begin{tabular}{|c|c|c|c|c|c|}
\hline \multirow{2}{*}{ No } & \multirow{2}{*}{ Pernyataan } & \multicolumn{4}{|c|}{ Jawaban (\%) } \\
\hline & & SS & $\mathbf{S}$ & TS & STS \\
\hline 1 & $\begin{array}{l}\text { Siswa mengerti dengan kriteria-kriteria penilaian yang digunakan untuk menilai } \\
\text { kegiatan mereka }\end{array}$ & 80 & 20 & 0 & 0 \\
\hline 2 & Siswa mengetahui skor setiap kriteria dalam rubrik penilaian & 20 & 60 & 20 & 0 \\
\hline 3 & $\begin{array}{l}\text { Siswa berusaha mencapai skor tertinggi dari kriteria-kriteria dalam rubrik } \\
\text { penilaian }\end{array}$ & 40 & 60 & 0 & 0 \\
\hline 4 & Siswa terlihat kritis saat menanggapi presentasi teman-temannya & 100 & 0 & 0 & 0 \\
\hline 5 & Siswa menggunakan banyak sumber untuk mengerjakan tugas performance & 100 & 0 & 0 & 0 \\
\hline 6 & Siswa mengumpulkan tugas project tepat waktu & 60 & 40 & 0 & 0 \\
\hline 7 & Hasil project siswa tergolong lengkap dan menarik & 80 & 0 & 20 & 0 \\
\hline 8 & Siswa sering konsultasi dengan guru mengenai kegiatan performance mereka & 80 & 20 & 0 & 0 \\
\hline 9 & Hasil project yang dikerjakan siswa terlihat kreatif & 40 & 60 & 0 & 0 \\
\hline 10 & $\begin{array}{l}\text { Kriteria-kriteria yang terkandung dalam rubrik penilaian disesuaikan dengan } \\
\text { kompetensi siswa }\end{array}$ & 0 & 20 & 60 & 20 \\
\hline 11 & Siswa terlihat aktif dalam mempersiapkan performance & 80 & 20 & 0 & 0 \\
\hline 12 & Siswa terlihat aktif saat presentasi & 60 & 40 & 0 & 0 \\
\hline 13 & Banyak pengetahuan yang baru, selain dari buku teks yang siswa tampilkan & 40 & 60 & 0 & 0 \\
\hline 14 & Siswa tidak keberatan dengan kriteria-kriteria dalam rubrik penilaian & 80 & 20 & 0 & 0 \\
\hline 15 & Siswa mampu menjawab pertanyaan-pertanyaan saat presentasi & 80 & 20 & 0 & 0 \\
\hline
\end{tabular}


Berdasarkan hasil tabel di atas maka berikut ini peneliti akan menguraikan dan membahas setiap pernyataan dari angket guru tersebut.

Siswa mengerti dengan kriteria-kriteria penilaian yang digunakan untuk menilai kegiatan mereka (80\% Sangat Setuju dan 20\% Setuju)

Dari hasil tersebut dapat disimpulkan siswa mengerti dengan kriteria-kriteria yang akan dipakai untuk menilai kegiatan mereka. Jika siswa tidak mengerti maka dampaknya adalah banyak siswa yang tidak mampu mencapai target pencapaian proses belajar yang diinginkan.

Siswa mengetahui skor setiap kriteria dalam rubrik penilaian $(60 \%$ Sangat Setuju dan $40 \%$ Setuju)

Dari hasil tersebut dapat disimpulkan bahwa semua guru berpendapat bahwa siswa mengetahui skor dari setiap kriteria-kriteria yang terkandung dalam rubrik penilaian berdasarkan penjelasan guru di awal pemberian tugas.

Siswa berusaha mencapai skor tertinggi dari kriteria-kriteria dalam rubrik penilaian $(60 \%$ Sangat Setuju dan 40\% Setuju)

Dari hasil tersebut dapat disimpulkan bahwa semua guru berpendapat bahwa siswa berusaha mencapai skor tertinggi dari kriteria-kriteria tersebut karena siswa memahami dengan jelas kriteriakriteria dalam rubrik penilaian.

Siswa terlihat kritis saat menanggapi presentasi teman-temannya (40\% Sangat Setuju dan 60\% Setuju)

Dari hasil tersebut dapat disimpulkan bahwa semua guru berpendapat bahwa siswa aktif dalam presentasi khususnya dalam bertanya ketika teman-temannya presentasi. Kriteria untuk menjawab pertanyaan juga merupakan bagian dari penilaian, oleh karena itu siswa berusaha untuk menjawab pertanyaan teman-tamannya. Siswa terlihat kritis karena ada siswa yang memang sengaja menguji temannya dan ada juga yang merasa tidak sungkan karena yang ditanya adalah temannya sendiri.

Siswa menggunakan banyak sumber untuk mengerjakankan tugas performance $(80 \%$ Setuju dan 20\% Tidak Setuju)

Dari hasil tersebut dapat disimpulkan bahwa sebagian besar guru berpendapat siswa berusaha mencari sumber-sumber lain selain buku teks yang mereka punya untuk mendapatkan informasi yang lebih dan nantinya informasi tersebut untuk memperlengkapi performance mereka. Menurut para guru biasanya siswa mencari sumber lain seperti internet karena paling mudah. Dengan banyaknya sumber yang digunakan oleh siswa dalam mengerjakan tugasnya maka semakin baik bagi proses pembelajaran siswa, karena dengan demikian siswa menjadi pembelajar yang mandiri.

Siswa mengumpulkan tugas project tepat waktu (60\% Sangat Setuju dan $40 \%$ Setuju)

Dari hasil tersebut dapat disimpulkan bahwa semua guru berpendapat bahwa siswa mengumpulkan tugas project tepat pada waktunya. Dari pernyataan guru tersebut nampak bahwa siswa termotivasi untuk memenuhi kriteria khususnya dalam hal waktu pengumpulan tugas. Menurut beberapa guru yang diwawancarai, siswa berusaha mengumpulkan tugas project tepat waktu bahkan lebih cepat dari waktu yang ditentukan karena siswa berusaha mencapai skor tertinggi yang merupakan bagian dari kriteria penilaian.

Hasil project siswa tergolong lengkap dan menarik (40\% Sangat Setuju dan 60\% Setuju)

Dari hasil tersebut dapat disimpulkan bahwa semua guru berpendapat hasil project siswa tergolong lengkap dan menarik. Dari pernyataan guru ini dapat diketahui bahwa project siswa tergolong lengkap karena siswa berusaha mencari informasi untuk melengkapi hasil projectnya, dan menarik artinya siswa berkreasi dalam mengerjakan tugas project.

Siswa sering konsultasi dengan guru mengenai persiapan performance mereka (20\% Sangat Setuju dan $80 \%$ Setuju)

Dari hasil tersebut dapat disimpulkan ada komunikasi antara siswa dengan guru selama siswa mempersiapkan dan mengerjakan tugas. Hal ini sangat baik karena guru mengetahui perkembangan siswa dalam mengerjakan tugas dan kesulitan-kesulitan apa yang dirasakan siswa selama mengerjakan tugas. Komunikasi yang baik antara guru dan siswa akan meningkatkan minat belajar siswa juga karena siswa merasa guru dapat memberikan solusi. Berdasarkan wawancara, beberapa guru juga mengatakan bahwa biasanya siswa melaporkan apa saja yang terjadi selama mengerjakan tugas project, bahwa sering siswa melaporkan kelakuan teman kelompoknya yang tidak mau bekerjasama 
dengan baik. Dengan demikian guru mampu memperingatkan siswa yang kurang bisa diajak kerjasama tersebut.

Hasil tugas project yang dikerjakan siswa terlihat kreatif (60\% Sangat Setuju dan 40\% Setuju)

Dari jawaban guru dapat disimpulkan, semua guru berpendapat bahwa hasil project siswa terlihat kreatif. Dari pernyataan guru juga dapat terlihat bahwa siswa juga termotivasi untuk kreatif dalam mengerjakan project. Hal ini sangat baik karena dengan demikian terbukti bahwa psikomotorik siswa berkembang.

Kriteria-kriteria yang terkandung dalam rubrik penilaian disesuaikan dengan kompetensi siswa $(60 \%$ Sangat Setuju dan $40 \%$ Setuju)

Dari hasil tersebut dapat disimpulkan bahwa kriteria-kriteria yang terkandung dalam rubrik penilaian disesuaikan dengan tingkat kompetensi siswa. Dalam hal ini guru sebagai penyusun kriteriakriteria dalam rubrik penilaian harus mengenal siswa-siswa yang akan dinilai, dan pengenalan ini mencakup pengetahuan dan tingkat kompetensi siswa.

Siswa terlihat aktif dalam mempersiapkan tugas performance (80\% Sangat Setuju dan $20 \%$ Setuju)

Dari hasil tersebut dapat disimpulkan siswa aktif dalam mempersiapkan performance, hal ini dapat terlihat dari keaktifan siswa dalam bertanya ketika menemukan kendala dalam mengerjakan tugas project.

Siswa terlihat aktif saat presentasi (60\% Sangat Setuju dan $40 \%$ Setuju)

Dari hasil tersebut dapat disimpulkan bahwa semua guru berpendapat siswa aktif dalam mempresentasikan materi yang diberikan. Siswa terlihat aktif saat presentasi dapat dilihat kemampuannya dalam menjelaskan materi dan pada saat menjawab pertanyaan-pertanyaan yang diajukan selama presentasi.

Banyak pengetahuan yang baru selain dari buku teks, yang siswa tampilkan (60\% Sangat Setuju dan $40 \%$ Setuju)

Dari hasil tersebut dapat disimpulkan bahwa banyak pengetahuan yang baru yang siswa tampilkan. Terlihat usaha siswa dalam memenuhi kriteria mengenai isi materi pelajaran. Tanpa siswa sadari siswa akhirnya mempunyai pengetahuan tambahan dari sumber lain, selain buku teks dan guru sebagai orang yang biasanya menjelaskan materi kepada siswa. Jika dihubungkan dengan wawancara guru maka salah seorang guru mengatakan bahwa, sering sekali siswa memberikan informasi yang lebih dan hal ini membuat guru tersebut kagum dengan usaha siswa tersebut.

Siswa tidak keberatan dengan kriteria-kriteria dalam rubrik penilaian (60\% Sangat Setuju dan 40\% Setuju)

Dari hasil tersebut dapat disimpulkan bahwa menurut pengamatan guru, siswa tidak keberatan dengan kriteria-kriteria yang berlakukan. Bukti dari pernyataan tersebut adalah siswa termotivasi dan berusaha memenuhi kriteria-kriteria dalam rubrik penilaian, sehingga siswa dapat mencapai kriteriakriteria dengan skor tertinggi.

Siswa mampu menjawab pertanyaan-pertanyaan saat presentasi $(60 \%$ Sangat Setuju dan $40 \%$ Setuju)

Dari hasil tersebut dapat disimpulkan bahwa siswa mampu menjawab pertanyaan yang dilontarkan saat presentasi. Dengan demikian nampak bahwa siswa menguasai materi yang dipresentasikannya dan mampu mempertanggungjawabkan saat presentasi.

\section{Analisis Angket Siswa}

Dari hasil analisis statistik pada angket siswa mengenai motivasi belajar siswa, didapat hasil sebagai berikut:

\begin{tabular}{llll}
\multicolumn{4}{c}{ Hasil Data Angket Siswa Dalam Persen (\%) } \\
\hline \multicolumn{3}{c}{ Keterangan } \\
\hline SS & Sangat Setuju & TS & Tidak Setuju \\
\hline S & Setuju & STS & Sangat Tidak Setuju \\
\hline
\end{tabular}

\begin{tabular}{|c|c|c|c|c|c|}
\hline \multirow{2}{*}{ No } & \multirow{2}{*}{ Pernyataan } & \multicolumn{4}{|c|}{ Jawaban (\%) } \\
\hline & & SS & $\mathbf{S}$ & TS & STS \\
\hline 1 & Tugas performance biasanya dikerjakan dalam kelompok & 39.84 & 54.47 & 5.69 & 0.00 \\
\hline 2 & $\begin{array}{l}\text { Guru selalu memberitahukan kriteria-kriteria yang dipakai dalam penilaian } \\
\text { performance }\end{array}$ & 53.66 & 40.65 & 4.88 & 0.81 \\
\hline
\end{tabular}




\begin{tabular}{|c|c|c|c|c|c|}
\hline 3 & Guru selalu memberitahukan hasil penilaian performance & 45.53 & 48.78 & 5.69 & 0.00 \\
\hline 4 & $\begin{array}{l}\text { Saya mendiskusikan dengan guru setiap kendala yang saya temui dalam } \\
\text { mengerjakan tugas performance }\end{array}$ & 15.45 & 54.47 & 26.83 & 3.25 \\
\hline 5 & $\begin{array}{l}\text { Selain buku teks saya juga menggunakan sumber lain untuk mempersiapkan } \\
\text { materi performance (misalnya: internet, koran, majalah, dan lain-lain) }\end{array}$ & 42.28 & 50.41 & 6.50 & 0.81 \\
\hline 6 & Saya antusias mempersiapkan materi yang akan dipresentasikan & 28.46 & 55.28 & 14.63 & 1.63 \\
\hline 7 & Saya aktif bertanya ketika teman-teman presentasi di kelas & 4.88 & 34.96 & 47.15 & 13.01 \\
\hline 8 & $\begin{array}{l}\text { Banyak pengetahuan baru yang saya dapatkan saat melihat performance teman- } \\
\text { teman }\end{array}$ & 17.07 & 62.60 & 19.51 & 0.81 \\
\hline 9 & Saya banyak mendapat pengetahuan baru saat mengerjakan tugas performance & 7.32 & 56.10 & 31.71 & 4.88 \\
\hline 10 & $\begin{array}{l}\text { Saya berusaha mencapai kriteria-kriteria dengan skor tertinggi dari penilaian } \\
\text { performance. }\end{array}$ & 29.27 & 64.23 & 4.88 & 1.63 \\
\hline 11 & Saya mampu berkreasi saat mengerjakan tugas project & 21.95 & 56.10 & 21.14 & 0.81 \\
\hline 12 & Saya berusaha bekerjasama dengan baik dalam kelompok & 9.76 & 54.47 & 32.52 & 3.25 \\
\hline 13 & Saya bangga jika tugas project saya dipajang di kelas & 56.10 & 32.52 & 8.94 & 2.44 \\
\hline 14 & Saya antusias mengerjakan tugas project & 12.20 & 56.10 & 30.89 & 0.81 \\
\hline 15 & Saya mengumpulkan tugas project tepat waktu & 26.83 & 65.04 & 8.13 & 0.00 \\
\hline 16 & Saya berusaha menjawab pertanyaan-pertanyaan saat presentasi & 20.33 & 60.16 & 18.70 & 0.81 \\
\hline 17 & Saya senang dengan kegiatan performance & 20.33 & 56.10 & 21.14 & 2.44 \\
\hline 18 & $\begin{array}{l}\text { Saya senang dengan sistem penilaian yang transparan (guru memberitahukan } \\
\text { kriteria-kriteria apa saja yang akan dinilai saat performance) }\end{array}$ & 34.15 & 58.54 & 7.32 & 0.00 \\
\hline
\end{tabular}

Berikut ini, peneliti akan menguraikan dan membahas setiap pernyataan dari angket siswa

Tugas performance biasanya dikerjakan dalam kelompok. (39.84\% Sangat Setuju, 54.47\% Setuju, $5.69 \%$ Tidak Setuju, dan 0\% Sangat Tidak Setuju)

Sebagian besar siswa menjawab sangat setuju dan setuju, jadi dari hasil tersebut dapat diketahui bahwa tugas performance biasanya dikerjakan dalam kelompok. Ada beberapa siswa yang menjawab tidak setuju karena kemungkinan siswa tersebut kurang berperan dalam kelompoknya, atau kemungkinan yang lain adalah siswa tersebut tidak mengerti arti dari tugas performance.

Guru selalu memberitahukan kriteria-kriteria yang dipakai dalam penilaian performance. (39.84\% Sangat Setuju, 54.47\% Setuju, 5.69\% Tidak Setuju, dan 0\% Sangat Tidak Setuju)

Dari hasil tersebut dapat diketahui bahwa guru selalu memberitahukan kriteria-kriteria yang dipakai untuk menilai tugas performance siswa, karena sebagian besar siswa menyatakan bahwa guru selalu mengkomunikasikan kriteria penilaian, namun ada juga beberapa siswa yang yang menyatakan tidak setuju. Hal ini kemungkinan karena siswa tidak konsentrasi pada saat guru menjelaskan mengenai kriteria-kriteria penilaian. Sangat disayangkan jika siswa tidak mengetahui kriteria-kriteria penilaian untuk menilai mereka karena dengan demikian siswa tidak dapat memotivasi dirinya untuk berusaha memenuhi kriteria yang ditetapkan dan tujuan dari proses pembelajaran siswa tersebut tidak tercapai.

Guru selalu memberitahukan hasil penilaian performance. (53.66\% Sangat Setuju, $40.65 \%$ Setuju, $0.81 \%$ Tidak Setuju, dan $4.88 \%$ Sangat Tidak Setuju)

Dari hasil tersebut dapat diketahui bahwa guru selalu memberitahukan hasil penilaian performance siswa, dengan demikian dapat disimpulkan bahwa guru selalu memberikan feed back setelah menilai siswa. Dapat juga disimpulkan bahwa ada sebagian kecil siswa yang merasa bahwa guru tidak memberitahukan mengenai hasil penilaian rubrik. Menurut wawancara, semua guru mengatakan bahwa dalam setiap penilaian, guru selalu mengembalikan hasil penilaian kepada siswa. Sangat mengherankan bahwa ada beberapa siswa yang merasa bahwa guru tidak selalu memberitahukan hasil penilaiannya. Kemungkinan besar hal ini disebabkan karena guru yang lalai atau siswa yang lalai dan tidak peduli dengan hasil penilaian guru. Sangat disayangkan jika siswa tidak menerima hasil penilaian guru, karena dengan demikian siswa tidak dapat mengevaluasi dirinya sehingga siswa tidak mengetahui letak kekuatan dan kelemahannya. Hal ini berdampak negatif dalam pembelajaran siswa karena siswa tidak tahu bagaimana harus meningkatkan proses pembelajarannya. Saya mendiskusikan dengan guru setiap kendala yang saya temui dalam mengerjakan tugas performance. (45.53\% Sangat Setuju, 48.78\% Setuju, 5.69\% Tidak Setuju, dan 0\% Sangat Tidak Setuju) 
Dari hasil tersebut dapat diketahui bahwa siswa mendiskusikan dengan guru setiap kesulitankesuliatan yang siswa temui selama mengerjakan tugas. Hal ini sangat baik karena dengan demikian ada komunikasi antara guru dan siswa dan guru dapat mengetahui perkembangan pembelajaran siswa. Saya menggunakan sumber lain, selain buku teks untuk mempersiapkan materi performance (misalnya: internet, koran, majalah, dll). (15.45\% Sangat Setuju, 54.47\% Setuju, 26.83\% Tidak Setuju, dan 3.25\% Sangat Tidak Setuju)

Dari hasil tersebut dapat diketahui bahwa sebagian besar siswa menggunakan sumber lain untuk mengerjakan tugas project mereka. Siswa termotivasi untuk belajar, hal ini terlihat dari usaha mereka untuk mencari sumber lain selain buku teks yang sering mereka gunakan di sekolah. Biasanya sumber yang digunakan adalah internet atau koran. Hal ini sangat baik bagi pembelajaran karena dengan demikian siswa menjadi pembelajar yang mandiri.

Saya antusias mempersiapkan materi-materi yang akan dipresentasikan. (42.28\% Sangat Setuju, $50.41 \%$ Setuju, $6.50 \%$ Tidak Setuju, dan $0.81 \%$ Sangat Tidak Setuju)

Dari hasil tersebut dapat diketahui bahwa sebagian besar siswa termotivasi dengan berusaha maksimal untuk mempersiapkan materi-materi yang akan dipresentasikan. Jika dihubungkan dengan hasil wawancara siswa, beberapa siswa berpendapat bahwa senang atau tidaknya mengerjakan tugas tergantung dari topik dan kegiatannya.

Saya aktif bertanya ketika teman-teman presentasi di kelas. (28.46\% Sangat Setuju, 55.28\% Setuju, $14.63 \%$ Tidak Setuju, dan 1.63\% Sangat Tidak Setuju)

Dari hasil tersebut dapat diketahui bahwa sebagian besar siswa aktif bertanya ketika presentasi berlangsung. Siswa termotivasi untuk belajar, hal ini terlihat dari keaktifan mereka untuk bertanya saat presentasi.

Banyak pengetahuan baru yang saya dapatkan saat melihat presentasi teman-teman. $(4.88 \%$ Sangat Setuju, 34.96\% Setuju, 47.15\% Tidak Setuju, dan 13.01\% Sangat Tidak Setuju)

Dari hasil tersebut dapat diketahui bahwa tidak semua siswa merasa mendapat pengetahuan baru saat teman-temannya presentasi. Lebih dari 50\% siswa yang menjawab tidak setuju. Dapat disimpulkan bahwa siswa kurang mendapat pengetahuan yang baru melalui presentasi temantemannya. Hal ini dapat disebabkan karena siswa merasa kebutuhannya dalam belajar tidak terpenuhi melalui informasi yang diperoleh dari teman-temannya, atau dapat juga disebabkan karena siswa merasa informasi dari guru lebih baik dari pada teman-temannya saat presentasi.

Saya banyak mendapat pengetahuan baru saat mengerjakan tugas performance. (17.07\% Sangat Setuju, 62.60\% Setuju, $19.51 \%$ Tidak Setuju, dan 0.81\% Sangat Tidak Setuju)

Dari hasil tersebut dapat diketahui siswa banyak yang mendapat pengetahuan baru saat mempersiapkan tugas performance. Jika dibandingkan dengan pernyataan pada nomor 8 maka dapat disimpulkan bahwa siswa merasa lebih banyak mendapat pengetahuan baru selama mengerjakan tugas performance dari pada saat melihat performance teman-temannya.

Saya berusaha mencapai kriteria-kriteria dengan skor tertinggi dari penilaian performance. (7.32\% Sangat Setuju, 56.10\% Setuju, 31.71\% Tidak Setuju, dan 4.88\% Sangat Tidak Setuju)

Dari hasil tersebut dapat diketahui bahwa sebagian besar siswa berusaha mencapai kriteriakriteria dengan skor tertinggi dari penilaian performance. Siswa termotivasi dengan adanya kriteriakriteria dalam rubrik penilaian.

Saya mampu berkreasi saat mengerjakan tugas project. (29.27\% Sangat Setuju, 64.23\% Setuju, 4.88\% Tidak Setuju, dan 1.63\% Sangat Tidak Setuju)

Dari hasil tersebut dapat diketahui bahwa sebagian besar siswa mampu berkreasi dalam pengerjakan tugas project. Dengan demikian aspek keterampilan siswa juga berkembang dalam mengerjakan tugas project.

Saya berusaha bekerja sama dengan baik dalam kelompok. $(21.95 \%$ Sangat Setuju, $56.10 \%$ Setuju, 21.14\% Tidak Setuju, dan 0.81\% Sangat Tidak Setuju)

Dari hasil tersebut dapat diketahui bahwa sebagian besar siswa berusaha untuk bekerja sama dengan teman-teman kelompoknya. Dapat disimpulkan bahwa siswa termotivasi dalam belajar, hal ini disebabkan karena karena kriteria dalam rubrik penilaian juga tercakup di dalam rubrik penilaian.

Saya bangga jika tugas project saya dipajang di kelas. (9.76\% Sangat Setuju, $54.47 \%$ Setuju, $32.52 \%$ Tidak Setuju, dan 3.25\% Sangat Tidak Setuju)

Dari hasil tersebut dapat diketahui bahwa sebagian besar siswa bangga jika hasil karyanya berupa tugas project di pajang dikelas. Namun ada juga siswa yang tidak senang. Hal ini dapat 
disebabkan oleh pengalaman siswa dimana selama ini siswa belum mampu membuat tugas project yang baik dan mendapatkan skor tertinggi.

Saya antusias mengerjakan tugas project. (56.10\% Sangat Setuju, $32.52 \%$ Setuju, $8.94 \%$ Tidak Setuju, dan $2.44 \%$ Sangat Tidak Setuju)

Dari hasil tersebut dapat diketahui bahwa siswa berusaha mengerjakan tugas project. Siswa termotivasi untuk memenuhi kriteria-kriteria dalam rubrik penilaian.

Saya mengumpulkan tugas project tepat waktu. (12.20\% Sangat Setuju, 56.10\% Setuju, 30.89\% Tidak Setuju, dan $0.81 \%$ Sangat Tidak Setuju)

Dari hasil tersebut dapat diketahui bahwa siswa berusaha mengumpulkan tugas project tepat waktu. Siswa termotivasi untuk memenuhi kriteria-kriteria yang tetapkan berhubungan dengan waktu pengumpulan tugas.

Saya berusaha menjawab pertanyaan-pertanyaan pada saat presentasi. (20.33\% Sangat Setuju, $60.16 \%$ Setuju, $18.70 \%$ Tidak Setuju, dan $0.81 \%$ Sangat Tidak Setuju)

Dari hasil tersebut dapat diketahui bahwa siswa berusaha aktif dalam menjawab setiap pertanyaan pada saat presentasi. Siswa termotivasi untuk belajar menguasai materi pembelajarannya.

Saya senang dengan kegiatan performance. (20.33\% Sangat Setuju, 56.10\% Setuju, $21.14 \%$ Tidak Setuju, dan $2.44 \%$ Sangat Tidak Setuju)

Dari hasil tersebut dapat diketahui bahwa siswa senang dengan pembelajaran dengan kegiatan performance.

Saya senang dengan sistem penilaian yang transparan dimana guru memberitahukan kriteriakriteria apa saja yang akan dinilai saat performance. (34.15\% Sangat Setuju, 58.54\% Setuju, 7.32 $\%$ Tidak Setuju, dan 0\% Sangat Tidak Setuju)

Dari hasil tersebut dapat diketahui bahwa siswa senang dengan sistem penilaian yang transparan dimana siswa mengetahui apa saja yang dinilai dalam hal ini mencakup kriteria-kriteria dalam rubrik penilaian yang prosedurnya harus dikomunikasikan dengan siswa sebelum penilaian tersebut diberlakukan kepada siswa.

\section{PEMBAHASAN}

Analisis data nilai siswa yang dinilai dengan menggunakan rubrik penilaian

Dari data nilai siswa yang didapatkan melalui rubrik penilaian, maka didapat bahwa tidak ada siswa yang termasuk pada skor 1 untuk setiap kriteria. Sangat jarang pada skor 2 dan kebanyakan siswa berada pada skor 3 dan 4. Dari data tersebut dapat disimpulkan bahwa siswa berusaha untuk memenuhi kriteria-kriteria dalam rubrik penilaian tersebut, dan usaha mereka terlihat dari skor pada skala 3 dan skala 4.

Menurut wawancara guru dan juga berdasarkan format penilaian yang disepakati oleh sekolah tersebut, penilaian kinerja siswa yang selama ini dinilai dengan menggunakan rubrik, mempunyai peranan sebayak $40 \%$ dan sisanya yaitu $60 \%$ berasal dari penilaian tertulis yang mencakup tes harian, ujian tengah semester dan ujian akhir semester. Artinya $40 \%$ nilai dari performance siswa yang mencakup presentasi, tugas project, dan parktikum terambil dari rubrik penilaian. Dari data ini maka dapat disimpulkan rubrik sebagai penilaian berperan penting dalam pembelajaran siswa di SMP Dian Harapan Karawaci.

\section{SIMPULAN DAN SARAN}

\section{Simpulan}

Guru memahami rubrik sebagai penilaian yang dapat menilai ketiga aspek pembelajaran siswa yaitu kognitif, psikomotorik, dan afektif. Guru juga memahami rubrik sebagai penilaia yang biasa digunakan untuk menilai performance siswa seperti presentasi, tugas project, dan praktikum siswa. Tanggapan para guru yaitu, guru merasa banyak terbantu dalam menilai siswa, memotivasi siswa belajar, dan mengevaluasi pengajarannya. Kesimpulan ini berdasarkan wawancara guru dan data angket guru. Siswa memahami rubrik sebagai penilaian yang menggunakan kriteria-kriteria seperti kreativitas, kerjasama, alat peraga, waktu pengumpulan dan lain-lain. Tanggapan siswa ialah, siswa senang dan berpendapat bahwa rubrik merupakan penilaian yang transparan dan adil karena siswa mengetahui kriteria-kriteria yang dipakai untuk menilai. Kesimpulan ini diperoleh berdasarkan wawancara siswa. 


\section{Saran}

Melihat banyaknya kekurangan dan keterbatasan dalam penelitian ini berdasarkan hasil analisis dan pembahasan, maka saran yang dapat diberikan untuk penelitian berikutnya adalah perlu adanya penelitian lanjutan dengan observasi kelas secara langsung dan bertahap, untuk melihat secara langsung kontribusi rubrik sebagai penilaian alternatif terhadap motivasi belajar dengan menganalisa hasil penilaian rubrik dengan hasil tes tulis.

\section{DAFTAR PUSTAKA}

Arends, R. I. (2012). Learning to Teach. New York: McGraw-Hill.

Emda, Amna (2017). Kedudukan Motivasi Belajar Siswa Dalam Pembelajaran. Lantanida Journal: Jurnal Ilmiah, 5 (2).

Imanuel W., Darius. (2017). Peran Jam Belajar Efektif Siswa Dalam Memoderatori Motivasi dalam Meningkatkan Hasil Belajar Siswa. Scholaria: Jurnal Pendidikan dan Kebudayaan, 7 (1),1016.

Permendikbud No. 64 (2013). Tentang Standar Isi Pendidikan Dasar dan Menengah.

Permendikbud No. 104 (2014). Tentang Kurikulum 2013 Sekolah Menengah Pertama/Madrasah Stanawiyah.

Permendikbud No. 58 (2014). Tentang Penilaian Hasil Belajar oleh Pendidik pada Pendidikan Dasar dan Pendidikan Menengah.

Raharjo, Andreas. (2010). Hubungan antara Multiple Intelligence dengan Prestasi Belajar Siswa Kelas XI di SMA Negeri 10 Malang. Jurnal Psikologi, 5(2).

Uno, Hamzah B. (2010). Teori motivasi \& pengukurannya: Analisis di bidang pendidikan. Jakarta: Bumi Aksara.

Van Brummelen, H. (2011). Berjalan dengan Tuhan di dalam kelas: Pendekatan Kristiani untuk pembelajaran [Walking with God in the class room: Christian approaches to learning and teaching]. Jakarta: Universitas Pelita Harapan. (Original work published 1998). 